\title{
PERANCANGAN PERANGKAT LUNAK ALAT UJI BIPOLAR JUNCTION TRANSISTOR BERBASIS MIKROKONTROLER
}

\author{
Jumiasih*), Trias Andromeda, and Munawar Agus Riyadi \\ Departemen Teknik Elektro, Universitas Diponegoro \\ Jl. Prof. Sudharto, SH, Kampus UNDIP Tembalang, Semarang 50275, Indonesia \\ ${ }^{*}$ E-mail : jumiasih2014@gmail.com
}

\begin{abstract}
Abstrak
Transistor merupakan salahsatu komponen penting dalam rangkaian elektronika. Transistor telah digunakan hampir disemua rangkaian elektronika. Namun, permasalahan sering timbul ketika ingin mengaplikasikan transistor ke dalam sebuah rangkaian elektronika, karena transistor sangat rentan terhadap kerusakan. Transistor bisa rusak karena suhu yang terlalu tinggi, kesalahan pengukuran, maupun kesalahan pemasangan dalam rangkaian. Hal ini karena cukup sulit mengetahui jenis maupun kaki-kaki dari transistor yang akan digunakan apabila tanpa panduan dari datasheet transistor tersebut. Bahkan datasheet transistor tidak memberikan data yang pasti mengenai nilai penguatan transistor (hanya berupa range maksimum-minimum). Pengecekan secara manual menggunakan multimeter dapat dilakukan untuk menentukan kaki-kaki transistor beserta nilai penguatannya, namun cara tersebut kurang praktis. Pengecekan kaki-kaki transistor dengan cara tersebut harus melalui beberapa tahapan dan ketelitian serta membutuhkan waktu yang cukup lama. Dalam penelitian ini, dirancang suatu perangkat pengujian transistor yang dapat membantu dalam pengecekan transistor BJT, melakukan identifikasi jenis transistor NPN dan PNP, identifikasi kaki-kaki transistor, mengetahui nilai penguatan (hFE) serta nilai tegangan forward (vf) dari transistor tersebut.
\end{abstract}

Kata kunci : Alat uji, Transistor, BJT, Mikrokontroler

\begin{abstract}
Transistors are one of the important components in electronic circuits. Transistors are currently in almost all electronic circuits. However, it often happens to apply the transistor to an electronic circuit, because the transistor is very susceptible to damage. Transistors can be damaged due to too high temperatures, measurement errors, or installation errors in the circuit. This is because it is quite difficult to know the types of transistors to be used from the transistor datasheet. Even the transistor datasheet does not provide definite data in the gain of a transistor (only in the form of a maximum-minimum range). Manually checking using a multimeter can be done to determine the legs of the transistor along with the reinforcement values, but this method is less practical. Checking the legs of the transistor in that way must go through several stages and accuracy and requires a long time. In this research, a transistor device is made that can assist in checking the BJT transistor, doing the type of transistor NPN and PNP, knowing the legs arrangements of the transistor, knowing the gain (hFE) and the forward voltage (vf) of the transistor.
\end{abstract}

Keywords: test equipment, transistor, BJT, microcontroller

\section{Pendahuluan}

Transistor adalah komponen aktif yang dibuat dari bahan semikonduktor. Transistor banyak digunakan hampir disemua rangkaian elektronika. Transistor memiliki banyak fungsi diantaranya, digunakan dalam amplifier atau penguat, sebagai saklar berkecapatan tinggi, stabilisasi tegangan, modulasi sinyal, maupun dikemas dalam bentuk IC. Transistor ada dua jenis yaitu FET (Field Effect Transistor) dan BJT (Bipolar Junction Transistor)[1].
Transistor bisa rusak karena suhu yang terlalu tinggi, kesalahan pemasangan kaki transistor dalam rangkaian, maupun faktor lainnya. Perubahan suhu akan bisa merubah titik kerja yang sudah ditetapkan pada suhu ruang. Hal ini bisa jadi akan mempengaruhi faktor penguatan tegangan dari suatu rangkaian penguat. Kesalahan pemasangan kaki transitor bisa berakibat fatal pada rangkaian elektronika, karena kaki transistor memiliki tugas dan fungsi yang berbeda-beda. Hal ini bisa jadi akan membuat rangkaian tidak berfungsi dengan maksimal atau tidak berfungsi sama sekali atau bahkan rusak[2]. 
Pengecekan secara manual menggunakan multimeter dapat dilakukan untuk menentukan kaki-kaki transistor beserta nilai penguatannya, namun cara tersebut kurang praktis, oleh karena itu, diperlukan suatu alat yang dapat melakukan tugas tersebut secara lebih praktis dan efisien. Dalam proyek penelitian ini dirancang suatu perangkat pengujian transistor bipolar (BJT). Melakukan identifikasi jenis transistor bipolar NPN dan PNP, mengidentifikasi kaki-kaki BJT (Kaki B, C, dan E), dan juga mengetahui nilai beta $(\beta / \mathrm{hFE})$ atau penguatan dari transistor tersebut.

Penelitian mengenai alat untuk mengecek transistor telah cukup banyak dilakukan. Seperti yang telah dilakukan oleh Kiki Hery Sandy mahasiswa lulusan Telkom University tahun 2010, berhasil menrancang alat untuk mengecek jenis dan nilai penguatan transistor dengan akurasi benar 93\%. Tetapi alat yang dirancang oleh Kiky Hery Sandy belum dapat membaca letak kaki transistor [3]. Penelitian yang dilakukan oleh Arief Hendra Saptadi, Eka Whyudi, dan Chandra AP Simorangkir, mahasiswa lulusan Akademi Teknik Telekomunikasi Sandhy Putra Purwokerto tahun 2010, mereka berhasil merancang alat yang dapat menghitung tingkat pembiasan dc transistor dengan tingkat eror $1,87 \%$. Tetapi alat yang dirancang belum dapat membaca jenis dan letak kaki transistor [4]. Penelitian yang dilakukan oleh Azizahwati, mahasiswi lulusan Pendidikan Fisika Universitas Riau, berhasil merancang alat yang dapat mengetahui keadaan transistor bagus untuk dijadikan sebagai saklar, penguat arus, penguat tegangan AC dan DC dengan tingkat eror $0 \%$. Tetapi alat yang dirancang oleh Azizahwati, belum dapat membaca jenis, dan letak kaki transistor [5].

Oleh karena itu, diperlukan suatu alat uji transistor tipe BJT yang memiliki fitur lebih lengkap dengan cara pengoperasian yang lebih praktis. Penelitian ini menghasilkan suatu pola dan parameter-parameter pengujian BJT, serta rancangan perangkat lunak sistem alat uji BJT yang mampu diterapkan untuk melakukan identifikasi jenis BJT, mengidentifikasi kaki-kaki BJT, mengetahui nilai penguatan (hFE) BJT, serta besar tegangan forward (Vf) secara lebih praktis dengan memanfaatkan teknologi mikrokontroler.

\section{Metode}

Perancangan alat uji BJT berbasis mikrokontroler dalam penelitian ini dibagi menjadi 2 bagian utama, yaitu perancangan perangkat keras (hardware) dan perancangan perangkat lunak (software). Hasil dari perancangan hardware sistem kemudian akan digunakan sebagai acuan dalam melakuakan perancangan software selanjutnya. Sedangkan untuk perancangan software, difokuskan pada 2 pokok bahasan yaitu mengenai penentan pola dan parameter uji serta pemrograman sistem.

Berikut ini hasil dari perancangan hardware sistem secara keseluruhan ditunjukkan dalam Gambar 1 :

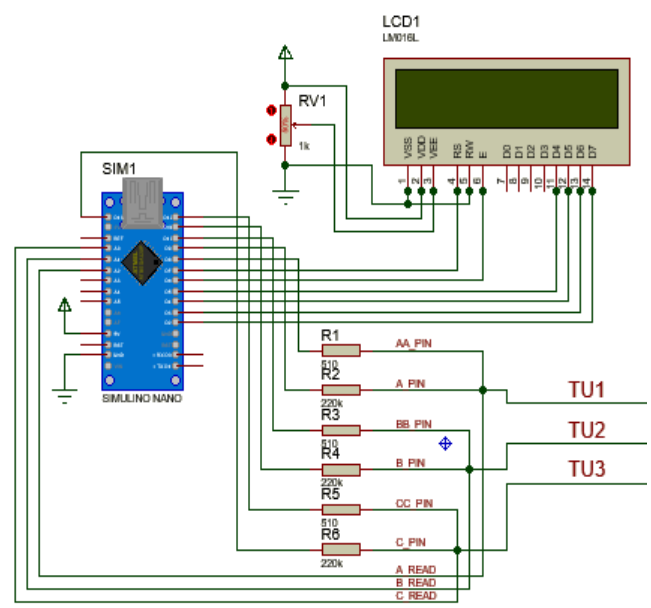

Gambar 1. Desain rangkaian alat uji[6]

\subsection{Penentuan Pola Parameter Uji}

Karena alat uji BJT ini didesain supaya memiliki fungsi untuk melakukan pengukuran terhadap tegangan forward (vf) dan nilai penguatan BJT (hFE), maka dalam perancangannya perlu ditentukan terlebih dahulu konfigurasi transistor seperti apa yang akan digunakan. Dalam perancangan penelitian ini, dipilih konfigurasi $\mathrm{CE}$ (Common Emitter) untuk BJT jenis NPN dan konfigurasi CC (Common Collector) untuk BJT jenis PNP. Dengan mengacu pada pemilihan nilai tahanan resistor pada perancangan perangkat keras yang sudah dibuat, digambarkan desain rangkaiannya pada Gambar 2 dan Gambar 3 di bawah ini.

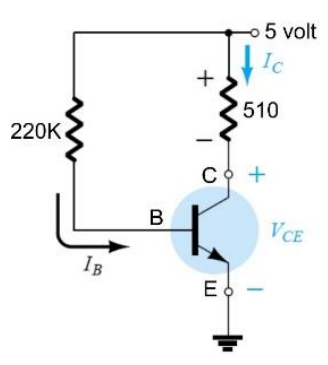

Gambar 2. Skema rangkaian CE (Common Emitter) untuk pengujian BJT jenis NPN

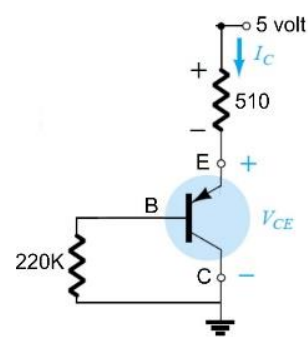

Gambar 3. Skema rangkaian CC (Common Collector) untuk pengujian BJT jenis PNP 
Dalam penelitian ini, alat uji BJT yang dihasilkan diharapan mampu melakukan identifikasi kaki-kaki BJT serta jenis BJT yang diuji. Untuk itu, diperlukan satu atau beberapa parameter yang bisa dijadikan sebagai acuannya. Pada produk ini, parameter yang digunakan adalah nilai hasil pembacaan tegangan di titik yang terkoneksi dengan VCC via resistor 510 Ohm. Gambar 4 dan Gambar 5 di bawah ini menunjukkan skema pembacaan tegangan di kaki kolektor BJT (pada NPN) dan kaki emitor BJT (pada PNP) menggunakan software simulasi Proteus 8.6.

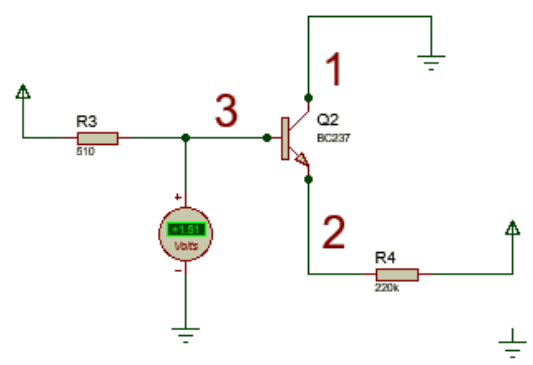

Gambar 4. Pengukuran tegangan pada rangkaian $\mathrm{CE}$ transistor NPN BC327 menggunakan software simulasi Proteus 8.6

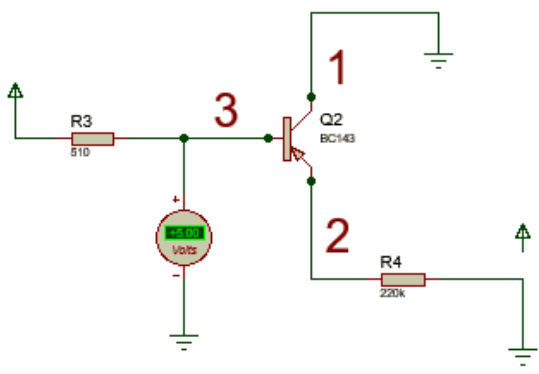

Gambar 5. Pengukuran tegangan pada rangkaian $\mathrm{CC}$ transistor PNP BC143 menggunakan software simulasi Proteus 8.6

Hasil pengukuran selengkapnya dari 5 buah BJT jenis NPN dan 5 buah BJT jenis PNP disajikan dalam tabel 1 dan tabel 2 dibawah ini.

Tabel 1. Percobaan pengukuran tegangan BJT jenis NPN menggunakan software Proteus 8.6

\begin{tabular}{|c|c|c|c|c|c|c|c|c|c|c|c|c|}
\hline & \multicolumn{12}{|c|}{$123=\mathrm{LTH}$} \\
\hline & \multicolumn{2}{|c|}{ BEC } & \multicolumn{2}{|c|}{ CEB } & \multicolumn{2}{|c|}{ BCE } & \multicolumn{2}{|c|}{ ECB } & \multicolumn{2}{|c|}{ EBC } & \multicolumn{2}{|c|}{ CBE } \\
\hline & $+\mathrm{T}$ & $-T^{-T}$ & $+\mathrm{T}$ & $-\mathrm{T}$ & $+\mathrm{T}$ & $-T$ & $+T$ & $-\mathrm{T}$ & $+\mathrm{T}$ & $-T^{-T}$ & $+\mathrm{T}$ & $-T$ \\
\hline$\overline{\mathrm{BC} 237}$ & 5 & 5 & 1.51 & 1.50 & 5 & 5 & 1.34 & 1.34 & 2.64 & 5 & 4.97 & 5 \\
\hline BC550 & 5 & 5 & 1.51 & 1.50 & 5 & 5 & 1.34 & 1.34 & 2.64 & 5 & 4.97 & 5 \\
\hline PN2222 & 5 & 5 & 0.84 & 0.84 & 5 & 5 & 0.83 & 0.83 & 3.30 & 5 & 4.94 & 5 \\
\hline TIP35 & 5 & 5 & 0.60 & 0.60 & 5 & 5 & 0.61 & 0.61 & 4.57 & 5 & 4.99 & 5 \\
\hline BC548 & 5 & 5 & $\begin{array}{l}1.51 \\
1.00\end{array}$ & $\begin{array}{l}.000 \\
1.50\end{array}$ & 5 & 5 & $\begin{array}{l}1.34 \\
\end{array}$ & 1.34 & 2.64 & 5 & 4.97 & 5 \\
\hline$\overline{\text { Rata }^{2}}$ & 5 & 5 & 1.19 & 1.19 & 5 & 5 & 1.10 & 1.10 & 3.16 & 5 & 4.97 & 5 \\
\hline
\end{tabular}

* Keterangan :

$\mathrm{L}=$ Low (dihubungkan ke GND)

$\mathrm{T}=$ Test (dihubungkan ke VCC kemudian ke GND via resistor $220 \mathrm{k} \Omega$ )

$\mathrm{H}=$ High (dihubungkan ke VCC via resistor $\quad 510 \Omega$ )
Tabel 2. Percobaan pengukuran tegangan BJT jenis PNP menggunakan software Proteus 8.6

\begin{tabular}{|c|c|c|c|c|c|c|c|c|c|c|c|c|}
\hline \multicolumn{13}{|c|}{$123=\mathrm{LTH}$} \\
\hline & \multicolumn{2}{|c|}{$\mathrm{BEC}$} & \multicolumn{2}{|c|}{ CEB } & \multicolumn{2}{|c|}{ BCE } & \multicolumn{2}{|c|}{ ECB } & \multicolumn{2}{|c|}{ EBC } & \multicolumn{2}{|c|}{ CBE } \\
\hline & $+\mathrm{T}$ & $-T$ & $+\mathrm{T}$ & $-T$ & $+\mathrm{T}$ & $-T$ & $+\mathrm{T}$ & $-T$ & $+\mathrm{T}$ & $-T$ & $+T$ & $-T$ \\
\hline BC327 & 1.14 & 1.13 & 5 & 5 & 1.11 & 1.11 & 5 & 5 & 5 & 4.97 & 5 & 4.04 \\
\hline PN2907 & 0.90 & 0.89 & 5 & 5 & 0.90 & 0.90 & 5 & 5 & 5 & 4.95 & 5 & 3.52 \\
\hline $\mathrm{BC} 14$ & 1.10 & 1.14 & 5 & 5 & 1.11 & 1.11 & 5 & 5 & 5 & 4.97 & 5 & 4.04 \\
\hline 2N3905 & 1.40 & 1.40 & 5 & 5 & 1.22 & 1.22 & 5 & 5 & 5 & 4.95 & 5 & 3.67 \\
\hline TIP34 & 0.60 & 0.60 & 5 & 5 & 0.61 & 0.61 & 5 & 5 & 5 & 4.95 & 5 & 4.60 \\
\hline Rata2 & 1.02 & 1.03 & 5 & 5 & 0.99 & 0.99 & 5 & 5 & 5 & 4.96 & 5 & 3.97 \\
\hline
\end{tabular}

*Keterangan : L = Low (dihubungkan ke GND)

$\mathrm{T}=$ Test (dihubungkan ke VCC kemudian ke GND via resistor $220 \mathrm{k} \Omega$ )

$\mathrm{H}=$ High (dihubungkan ke VCC via resistor 510 凡)

Dengan memperhatikan pola tegangan terukurnya pada konfigurasi CBE dan EBC, maka diperoleh suatu kesimpulak sebagai berikut :

1. Jika v2 $>4800 \mathrm{mv}$ dan v1<4800 mv maka BJT uji tersebut adalah BJT tipe NPN dengan konfigurasi kaki sebagai berikut :

$$
\begin{array}{ll}
>\quad \text { state } \mathrm{L}=\text { kaki } \mathrm{E} \text { (emitor) } \\
>\quad \text { state } \mathrm{T}=\text { kaki } \mathrm{B} \text { (basis) } \\
>\quad \text { state } \mathrm{H}=\text { kaki C (kolektor) }
\end{array}
$$

2. Jika v1>4800mv dan v2<4800 mv maka BJT uji tersebut adalah BJT tipe PNP dengan konfigurasi kaki sebagai berikut :

$$
\begin{aligned}
& >\quad \text { state } \mathrm{L}=\text { kaki } \mathrm{C} \text { (kolektor) } \\
& >\quad \text { state } \mathrm{T}=\text { kaki } \mathrm{B} \text { (basis) } \\
& >\quad \text { state } \mathrm{H}=\text { kaki } \mathrm{E} \text { (emitor) }
\end{aligned}
$$

\subsection{Pemrograman Sistem}

Dengan mengacu pada desain sistem secara keseluruhan seperti terdapat pada Gambar 1 dan berpegang pada pin diagram Arduino Nano maka pemetaan untuk penggunaan port pin mikrokontroler dalam sistem alat uji BJT ini sudah dapat dirancang. Berikut perancangannya ditunjukkan pada Gambar 6 di bawah ini :

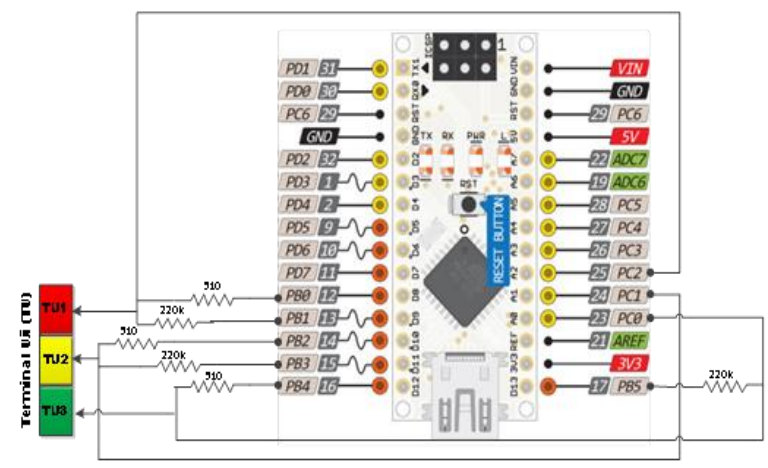

Gambar 6. Pemetaan port pin pengujian

Gambar 6 diatas merupakan pedoman untuk pembuatan rancangan pemrograman mikrokontroler selanjutnya. Berikut ini adalah rancangan algoritma programnya : 
1. Melakukan inisialisasi pin $\mathrm{I} / \mathrm{O}$ dan pendeklarasian variabel.

2. Melakukan pengkondisian port pin ATmega328P.

3. Pembacaan nilai tegangan.

4. Melakukan proses pengujian berdasarkan pola dan parameter yang didapat.

5. Mengirimkan data hasil pengujian dan menampilkannya pada LCD $16 \times 2$.

Algoritma diatas juga disajikan dalam bentuk diagram alir (flowchart) sebagaimana tercantum dalam Gambar 7.

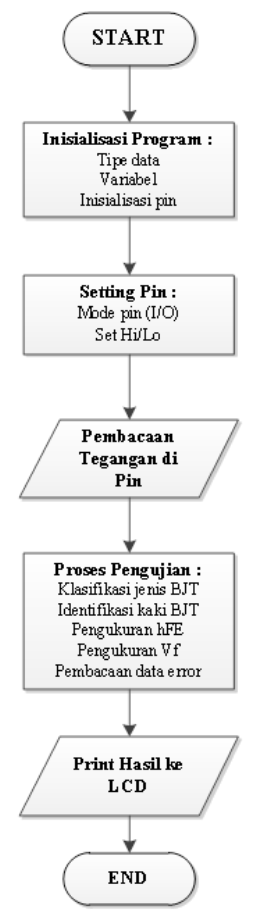

Gambar 7. Diagram alir pemrograman sistem

\subsubsection{Inisialisasi Program}

Langkah pertama yang harus dilakukan sebelum program utama dijalankan, adalah melakukan inisialisasi terlebih dahulu. Inisialisasi yang dilakukan mencakup inisialisasi tipe data dan variabel serta inisialisasi pin-pin I/O.

\subsubsection{Pengkondisian (Setting) Pin}

Di dalam tiap-tiap boolean yang dibuat, terdapat program untuk mengkondisikan terminal-terminal uji sedemikian rupa sehingga diperoleh hasil pembacaan tegangan yang berbeda-beda untuk kombinasi pengkondisian terminal yang berbeda pula. Nilai-nilai pembacaan tegangan inilah yang akan dijadikan dasar dalam penentuan hasil pengujian BJT. Berikut disajikan Tabel kombinasi pengkondisian terminal uji yang digunakan dalam perancangan software pada penelitian ini :
Tabel 3. Kombinasi pengkondisian terminal uji dan pengukuran[7]

\begin{tabular}{clll}
\hline No. & \multicolumn{3}{c}{ State Pin } \\
\cline { 2 - 4 } & TU 1 & TU 2 & TU 3 \\
\hline 1. & Positive & Negative & Test \\
2. & Positive & Test & Negative \\
3. & Test & Negative & Positive \\
4. & Test & Positive & Negative \\
$\mathbf{5 .}$ & Negative & Test & Positive \\
6. & Negative & Positive & Test \\
\hline *keterangan : TU (Terminal Uji) &
\end{tabular}

Setiap terminal uji (1, 2, maupun 3) dapat dikondisikan sebagai input maupun output baik digital maupun analog. Masing-masing dari ketiga terminal pada alat uji BJT ini dibangun dengan 3 buah port pin ATmega328P pada modul mikrokontroler arduino nano. Berikut adalah gambaran sederhana arsitektur dari terminal uji 2 yang telah dirancang dalam penelitian ini :

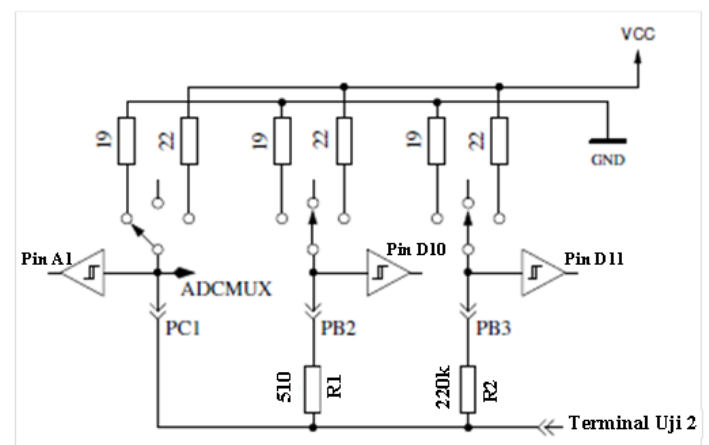

Gambar 8. Skema rancangan port pin I/O ATmega328P pada terminal uji 2 (TU2)

Untuk melakukan pengkondisian terminal uji seperti pada Gambar 8, maka port pin I/O ATmega pada TU yang bersangkutan harus disetting sebagai output dan diberikan kondisi state pin sesuai Tabel 3, apakah positif, negatif, atau test. State "Positive" pada Tabel 3 maksudnya adalah pin yang diaktifkan pada TU dikoneksikan ke VCC baik secara langsung, maupun dilewatkan melalui resistor 510 Ohm atau 220k Ohm. State "Negatif" maksudnya adalah pin yang diaktifkan pada TU dikoneksikan ke GND baik secara langsung, maupun dilewatkan melalui resistor 510 Ohm atau 220k Ohm. Sedangkan state "Test" maksudnya adalah bahwa TU disetting dengan 2 keadaan yaitu terhubung ke VCC kemudian dihubungkan ke GND dengan pilihan pengaktifan pin yang sama dengan dua state sebelumnya.

Program ini dalam perancangannya, menggunakan fungsi boolean dan beberapa kali inisialisasi port pin untuk port pin yang sama. Register yang diatur antara lain register PortA, PortB, PortC, dan PortD. Berikut ini penyajiannya dalam Tabel 4. 
Tabel 4. Port pin yang diaktifkan untuk masing-masing kombinasi pengkondisian terminal uji

\begin{tabular}{cllll}
\hline No. & Pengkondisian TU & \multicolumn{1}{c}{ TU 1 } & \multicolumn{1}{c}{ TU2 } & \multicolumn{1}{c}{ TU3 } \\
\hline 1. & Kombinasi 1 & PB0 - VCC & PC1 - GND & PB5 - TEST \\
2. & Kombinasi 2 & PB0 - VCC & PB3 - TEST & PC0 - GND \\
3. & Kombinasi 3 & PB1 - TEST & PC1 - GND & PB4 - VCC \\
4. & Kombinasi 4 & PB1 - TEST & PB2 - VCC & PC0 - GND \\
5. & Kombinasi 5 & PC2 - GND & PB3 - TEST & PB4 - VCC \\
6. & Kombinasi 6 & PC2 - GND & PB2 - VCC & PB5 - TEST \\
\hline
\end{tabular}

\subsubsection{Pembacaan Tegangan}

Perancangan senarai program pada bagian pembacaan input/masukan diutamakan pada input yang sifatnya analog. Hasil pembacaan tersebut harus dirubah nilainya supaya dapat direpresentasikan dalam rentang tegangan 0 sampai 5 volt sesuai rentang tegangan yang mampu dibaca oleh pin A0-A7 pada Arduino Nano.

Pin pembacaan tegangan pada kombinasi TU1 akan berbeda dengan pin pembacaan tegangan pada kombinasi TU2 dan seterusnya. Tegangan yang dibaca adalah tegangan pada pin state "positive" dan tegangan pada pin state "Test". Untuk lebih jelasnya, dibawah ini disajikan dalam Gambar :

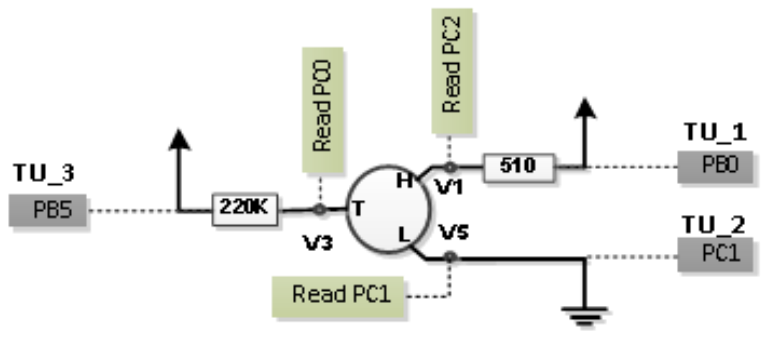

Gambar 9. Skema rangkaian pengukuran tegangan v1 dan v3 untuk pengkondisian TU kombinasi 1

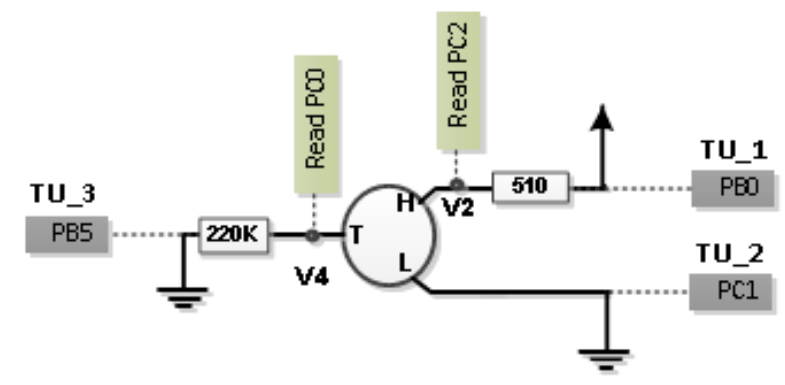

Gambar 10. Skema rangkaian pengukuran tegangan v2 dan v4 pengkondisian TU kombinasi 1

Hasil pembacaan dari A0, A1, maupun A2 yang merupakan nilai output dari pin-pin digital yang terhubung padanya, masih berupa nilai ADC sehingga untuk mendapatkan nilai output berupa tegangan dengan rentang 0 - 5 volt, diperlukan adanya proses konversi. Karena port input analog dari pin-pin analog yang dipakai untuk melakukan pembacaan tegangan (pin A0, A1, dan A2) memiliki resolusi 10 bit, maka rumus konversinya dapat dituliskan dalam persamaan 3.1 berikut ini :

$V_{A D C}=\left(\frac{A D C}{1023}\right) \times 4980$

Dimana:

$V_{A D C}=$ nilai pembacaan hasil konversi (mv)

$A D C=$ nilai $\mathrm{ADC}$ yang terbaca

Untuk pembacaan nilai tegangan pada pengkondisian TU kombinasi lain, port pin yang disetting dengan mode input untuk melakukan pembacaan tegangan ditujukkan dengan Tabel 5 dibawah ini :

Tabel 5. Port pin pembaca nilai tegangan pada tiap kombinasi pengkondisian TU

\begin{tabular}{ccccccc}
\hline & Kom-1 & Kom-2 & Kom-3 & Kom-4 & Kom-5 & Kom-6 \\
\hline V1 & PC2 & PC2 & PC1 & PC1 & PC2 & PC1 \\
V2 & PC2 & PC2 & PC1 & PC1 & PC2 & PC1 \\
V3 & PC0 & PC1 & PC2 & PC2 & PC1 & PC2 \\
V4 & PC0 & PC1 & PC2 & PC2 & PC1 & PC2 \\
\hline
\end{tabular}

\subsubsection{Penentuan Parameter Uji}

Untuk memperoleh keluaran dari hasil pengujian, diperlukan beberapa nilai sebagai parameter uji. Parameter-parameter uji ini diperoleh dari hasil pembacaan tegangan pada pin-pin analog arduino (port pin PC0, PC1, dan PC2). Nilai-nilai tersebut kemudian dibandingkan satu sama lain, kemudian dengan mengacu pada Tabel 1 dan Tabel 2 mengenai analisis pola tegangan yang sudah dibuat sebelumnya, kaki-kaki dan jenis BJT dapat diidentifikasi. Nilai penguatan BJT (hFE) dan besarya tegangan forward (Vf) juga dapat dihitung.

\section{A. Identifikasi Jenis dan Kaki BJT}

Algoritma dari proses identifikasi jenis dan konfigurasi kaki BJT sebagai berikut :

1. Kondisikan state pin "Test" dengan logika High, kemudian ukur tegangan v1 dan v3 seperti yang tertera pada Gambar 9.

2. Kondisikan state pin "Test" dengan logika Low, kemudian ukur tegangan v2 dan v4 seperti yang tertera pada Gambar 10.

3. Bandingkan tegangan-tegangan yang diperoleh dan buat statement dari nilai-nilai variabel v1, v2, v3, dan v4 tersebut dengan memperhatikan pola yang telah diperoleh dari kesimpulan data Tabel 1 dan 2 sebagai acuannya.

4. Buat kedalam fungsi IF untuk pengeksekusian perintah dalam program.

5. Print hasil pengujian ke LCD apabila ditemukan nilai yang sesuai.

Pada tiap kombinasi pengkondisian TU (terminal uji), terlebih dahulu ditentukan asumsi keluaran berupa jenis dan konfigurasi kaki BJT. Asumsi keluaran sistem berbeda 
untuk tiap-tiap kombinasinya, datanya disajikan dalam Tabel 6 dibawah ini :

Tabel 6. Port pin pembaca nilai tegangan pada tiap kombinasi pengkondisian $\mathrm{TU}$

\begin{tabular}{clcccccc}
\hline \multirow{2}{*}{ No. } & \multirow{2}{*}{ Pengkondisian TU } & \multicolumn{2}{c}{ TU1 } & \multicolumn{2}{c}{ TU2 } & \multicolumn{2}{c}{ TU3 } \\
\cline { 3 - 7 } & & NPN & PNP & NPN & PNP & NPN & PNP \\
\hline 1. & Kombinasi 1 & C & E & E & B & B & C \\
\hline 2. & Kombinasi 2 & C & E & B & B & E & C \\
\hline 3. & Kombinasi 3 & B & B & E & C & C & E \\
\hline 4. & Kombinasi 4 & B & B & C & E & E & C \\
\hline 5. & Kombinasi 5 & E & C & B & B & C & E \\
\hline 6. & Kombinasi 6 & E & C & C & E & B & B \\
\hline
\end{tabular}

B. Perhitungan Nilai Penguatan BJT (hFE)

Pada perancangan alat uji BJT ini juga sudah ditentukan konfigurasi rangkaiannya yaitu menggunakan konfigurasi common emitter (CE) untuk BJT jenis NPN dan menggunakan konfigurasi common collector (CC) untuk BJT jenis PNP. Berikut ini adalah rumus umum untuk menghitung nilai penguatan BJT (nilai hFE)[8] .

$$
\begin{aligned}
& h F E=\frac{I c}{I b} \\
& I e=I c+I b
\end{aligned}
$$

Dimana, $h F E=$ nilai penguatan $\mathrm{BJT}$

$$
\begin{aligned}
I c & =\text { Arus pada kaki C (kolektor) } \\
I b & =\text { Arus pada kaki B (basis) } \\
I e & =\text { Arus pada kaki E (emitor) }
\end{aligned}
$$

C. Perhitungan Nilai Tegangan Forward (Vf)

$$
\begin{array}{ll}
\text { Perhitungan NPN } & \text { Perhitungan PNP } \\
I b=v 3 / 220000 & I b=v 3 / 220000 \\
I c=v 1 / 510 & I e=v 2 / 510 \\
& I c=I e-I b
\end{array}
$$

Untuk melakukan perhitungan nilai tegangan forward (Vf) maka parameter yang diperlukan hanyalah nilai tegangan di kaki basis (B) dan nilai teangan di kaki emitor (E), karena pengertian tegangan forward sendiri merupakan beda tegangan antara basis dan emitor $\left(\mathrm{V}_{\mathrm{BE}}\right)$. Tegangan basis pada BJT uji jenis NPN dinotasikan dengan variabel v3 sedangkan untuk BJT uji jenis PNP dinotasikan dengan variabel v4. Sedangkan tegangan emitor pada BJT uji jenis NPN dinotasikan dengan variabel v5 sedangkan untuk BJT uji jenis PNP dinotasikan dengan variabel v2. Skema pengukurannya dapat dilihat pada Gambar 9 (untuk BJT jenis NPN) dan Gambar 10 (untuk BJT jenis PNP)[8].

Rumus yang digunakan untuk menghitung besar Vf adalah sebagai berikut :

Perhitungan NPN

$v f=v 3-v 5$
Perhitungan PNP

$v f=v 2-v 4$

Dimana, $v f=$ tegangan forward/forward voltage $(\mathrm{mv})$

\subsubsection{Penampil Hasil Uji BJT}

Hasil dari pengujian BJT yang berupa data jenis BJT, konfigurasi kaki BJT serta nilai hFE dan vf akan ditampilkan melalui layar LCD 16x2. Rancangan tampilannya adalah sebagai berikut :

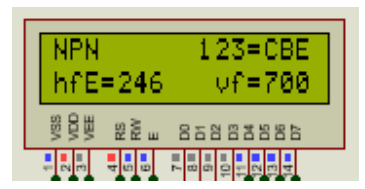

Gambar 11. Rancangan penampilan hasil uji BJT pada LCD $16 \times 2$

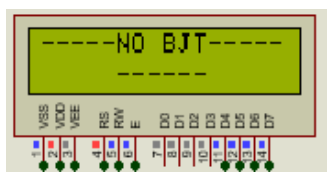

Gambar 12. Rancangan penampilan hasil uji BJ pada LCD 16x2 kondisi error

Untuk dapat menampilkan hasil uji BJT seperti pada Gambar 11 dan 12 diatas, maka terlebih dahulu library dari LCD 16x2 ini harus dimasukkan kedalam program dan dilakukan pemetaan port pin LCD terhadap arduino, kemudian LCD diaktifkan dengan cara memanggilnya dalam void setup dengan perintah lcd.begin(16, 2) . Senarai kode diatas hanya merupakan contoh dari salahsatu BJT uji tipe NPN, untuk BJT lain yang berbeda, tentu akan berbeda pula hasil tampilannya. Kondisi error akan ditampilkan apabila semua kombinasi pengkondisian terminal uji (TU) tidak memenuhi syarat yang telah ditentukan.

\section{Hasil dan Analisis \\ 3.1. Pengujian dan Analisa}

Pengujian perangkat lunak (software) dilakukan untuk menguji kemampuan dari proses pengolahan dan perhitungan data dalam menunjang proses pengujian transistor tipe BJT ini. Pada pengujian perangkat lunak ini dilakukan pengujian terhadap pola yang didapatkan dari simulasi pada saat merancang perangkat lunak. Parameter yang diukur/diuji merupakan parameter uji keseluruhan sistem yang meliputi pengujian jenis BJT, konfigurasi kaki BJT, hFE, dan forward voltage BJT (Vf). Semua parameter/nilai yang menjadi keluaran sistem dan tertampil di LCD kemudian dibandingkan dengan datasheet masing-masing BJT uji. 


\subsubsection{Pengujian Jenis BJT}

Pengujian pertama yang dilakukan adalah mengidentifikasi jenis dari BJT yang diuji menggunakan alat uji BJT yang telah dibuat. Pengujian dilakukan terhadap BJT jenis NPN dan BJT jenis PNP. Hasil pengujian ini kemudian dibandingkan dengan datasheet masing-masing BJT yang diuji sehingga dapat diketahui apakah alat uji BJT yang dibuat sudah berhasil melakukan identifikasi jenis BJT uji dengan benar atau belum. Berikut adalah prosedur pengujian yang dilakukan untuk menguji jenis dari BJT uji

1. Hubungkan alat uji BJT dengan sumber baterai 9 volt, kemudian nyalakan alat uji dengan menekan saklar ke posisi "on".

2. Atur kontras pada LCD dengan memutar potensiometer supaya karakter-karakter yang muncul pada LCD terlihat dengan jelas.

3. Masukkan BJT yang ingin diuji ke dalam socket uji, kemudian tarik tuas pengunci yang terdapat pada socket uji.

4. Tekan push button (tombol yang berwarna kuning pada alat), dan tunggu beberapa saat sampai hasil pengujiannya ditampilkan pada LCD.

5. Amati data keluaran LCD, lihat hasil pengujian jenis BJT uji pada layar LCD baris pertama sebelah kiri, kemudian bandingkan hasil pengujian yang diperoleh dengan datasheet BJT yang bersangkutan.

Setelah membandingkan hasil keluaran alat uji dengan data yang tertera pada datasheet BJT yang diuji, maka perbandingannya disajikan dalam bentuk Tabel 7 dibawah ini :

Tabel 7. Perbandingan antara jenis BJT hasil pengujian dan jenis BJT pada datasheet

\begin{tabular}{|c|c|c|c|c|}
\hline \multirow{2}{*}{ BJT Uji } & \multirow{2}{*}{ Tampilan LCD } & \multicolumn{2}{|c|}{ Jenis BJT } & \multirow{2}{*}{ Keterangan } \\
\hline & & Alat $\mathrm{Uji}$ & Datashet & \\
\hline $\mathrm{BC} 237$ & $F^{2 x}=0$ & NPN & NPN & SESUAI \\
\hline BC547 & & NPN & NPN & SESUAI \\
\hline C1815 & $F^{2}=-2 x$ & PNP & NPN & SESUAI \\
\hline S9012 & es & PNP & PNP & SESUAI \\
\hline BC546B & सि: & NPN & NPN & SESUAI \\
\hline BC557 & $=1285$ & PNP & PNP & SESUAI \\
\hline $\mathbf{S 8 0 5 0}$ & 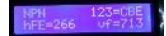 & NPN & NPN & SESUAI \\
\hline 2N3904 & & NPN & NPN & SESUAI \\
\hline 2N5401 & 8 & PNP & PNP & SESUAI \\
\hline A1015 & $P P P=21,123=86$ & PNP & PNP & SESUAI \\
\hline
\end{tabular}

Tabel 7 diatas menyajikan perbandingan antara data hasil identifikasi jenis BJT menggunakan alat uji BJT berbasis mikrokontroler yang telah dibuat dengan data jenis BJT yang terdapat dalam datasheet BJT yang bersangkutan. Dapat dilihat bahwa dari sample 10 BJT diatas, semua hasil pengujiannya sudah sesuai dengan datasheet, sehingga dapat disimpulkan bahwa alat uji BJT yang dibuat telah mampu melakukan identifikasi jenis BJT uji secara benar.

\subsubsection{Pengujian Konfigurasi Kaki BJT}

Prosedur yang dilakukan untuk melakukan pengujian konfigurasi kaki BJT ini sama dengan prosedur pengujian jenis BJT sebelumnya, namun yang diamati disini adalah hasil pengujian konfigurasi kaki nya pada LCD baris pertama sebelah kanan. Setelah membandingkan hasil keluaran alat uji dengan data yang tertera pada datasheet BJT yang diuji, maka perbandingannya disajikan dalam bentuk Tabel 8 dibawah ini :

Tabel 8. Perbandingan antara konfigurasi kaki BJT hasil pengujian dan konfigurasi kaki BJT pada datasheet

\begin{tabular}{|c|c|c|c|c|}
\hline \multirow{2}{*}{ BJT Uji } & \multirow{2}{*}{ Tampilan LCD } & \multicolumn{2}{|c|}{ Pemasangan Kaki } & \multirow{2}{*}{ Keterangan } \\
\hline & & Alat Uji & Datashet & \\
\hline $\mathrm{BC} 237$ & Exes & $E$ & EBC & SESUAI \\
\hline BC547 & 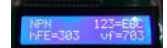 & & EBC & SESUAI \\
\hline C1815 & 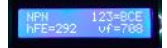 & & BCE & SESUAI \\
\hline S9012 & Fe & & CBE & SESUAI \\
\hline BC546B & 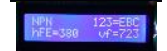 & & EBC & SESUAI \\
\hline BC557 & & & EBC & SESUAI \\
\hline S8050 & 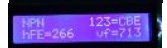 & & CBE & SESUAI \\
\hline 2N3904 & & & CBE & SESUAI \\
\hline 2N5401 & - & & CBE & SESUAI \\
\hline A1015 & 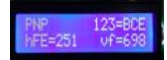 & & BCE & SESUAI \\
\hline
\end{tabular}

Tabel 8 diatas menyajikan perbandingan antara data hasil identifikasi konfigurasi kaki BJT menggunakan alat uji BJT berbasis mikrokontroler yang telah dibuat dengan data konfigurasi kaki BJT yang terdapat dalam datasheet BJT yang bersangkutan. Dapat dilihat bahwa dari sample 10 BJT diatas, semua hasil pengujiannya sudah sesuai dengan datasheet, sehingga dapat disimpulkan bahwa alat uji BJT yang dibuat telah mampu melakukan identifikasi konfigurasi kaki BJT uji secara benar.

\subsubsection{Pengujian Nilai Penguatan BJT (hFE)}

Prosedur yang dilakukan untuk melakukan pengujian nilai hFE BJT ini sama dengan prosedur pengujian jenis BJT sebelumnya, namun yang diamati disini adalah hasil pengujian konfigurasi kaki nya pada LCD baris kedua sebelah kiri. Setelah membandingkan hasil keluaran alat uji dengan data yang tertera pada datasheet BJT yang diuji, maka perbandingannya disajikan dalam bentuk Tabel 9 dibawah ini : 
TRANSIENT, VOL. 8, NO. 1, MARET 2019, e-ISSN:2685-0206

Tabel 9. Perbandingan antara nilai penguatan (hFE) hasil pengujian dan nilai hFE pada datasheet

\begin{tabular}{|c|c|c|c|c|}
\hline \multirow{2}{*}{ BJT Uji } & \multirow{2}{*}{ Tampilan LCD } & \multicolumn{2}{|c|}{ hFE BJT } & \multirow{2}{*}{ Keterangan } \\
\hline & & Alat Uji & Datashet & \\
\hline BC237 & 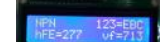 & 227 & $120-800$ & SESUAI \\
\hline BC547 & thite-305 & 303 & $110-800$ & SESUAI \\
\hline C1815 & & 292 & $70-700$ & SESUAI \\
\hline S9012 & InE & 270 & $\begin{array}{c}\text { Maksimal } \\
300\end{array}$ & SESUAI \\
\hline BC546B & hithesse & 380 & $200-540$ & SESUAI \\
\hline BC557 & 12 & 333 & $100-800$ & SESUAI \\
\hline $\mathbf{S} 8050$ & 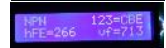 & 266 & $40-400$ & SESUAI \\
\hline $2 \mathrm{~N} 3904$ & & 232 & $100-300$ & SESUAI \\
\hline 2N5401 & & 142 & $60-240$ & SESUAI \\
\hline A1015 & 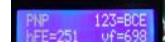 & 251 & $70-400$ & SESUAI \\
\hline
\end{tabular}

Tabel 9 diatas menyajikan perbandingan antara data hasil perhitungan nilai hFE BJT menggunakan alat uji BJT berbasis mikrokontroler yang telah dibuat dengan data rentang hFE BJT yang diperbolehkan dalam datasheet BJT yang bersangkutan. Dapat dilihat bahwa dari sample 10 BJT diatas, semua hasil pengujiannya sudah sesuai dengan datasheet, sehingga dapat disimpulkan bahwa alat uji BJT yang dibuat telah mampu melakukan peritungan nilai hFE BJT uji secara benar.

\subsubsection{Pengujian Nilai Tegangan Forward BJT (vf)}

Pengujian keempat yang dilakukan adalah mengidentifikasi nilai tegangan forward (vf) BJT yang diuji menggunakan alat uji BJT yang telah dibuat. Pengujian dilakukan terhadap 5 BJT jenis NPN dan 5 BJT jenis PNP. Hasil pengujian ini kemudian dibandingkan dengan datasheet masing-masing BJT yang diuji sehingga dapat diketahui apakah alat uji BJT yang dibuat sudah berhasil melakukan identifikasi jenis BJT uji dengan benar atau belum.

Prosedur yang dilakukan untuk melakukan pengujian nilai vf BJT ini sama dengan prosedur pengujian jenis BJT sebelumnya, namun yang diamati disini adalah hasil pengujian konfigurasi kaki nya pada LCD baris kedua sebelah kanan. Setelah membandingkan hasil keluaran alat uji dengan data yang tertera pada datasheet BJT yang diuji, maka perbandingannya disajikan dalam bentuk Tabel 10 .
Tabel 10. Perbandingan antara nilai tegangan forward (vf) hasil pengujian dan nilai vf pada datasheet

\begin{tabular}{|c|c|c|c|c|}
\hline \multirow{2}{*}{ BJT Uji } & \multirow{2}{*}{ Tampilan LCD } & \multicolumn{2}{|c|}{ vf BJT (mv) } & \multirow{2}{*}{ Keterangan } \\
\hline & & Alat Uji & Datashet & \\
\hline $\mathrm{BC} 237$ & Fin: & 713 & $\leq 830$ & SESUAI \\
\hline BC547 & & 703 & $\begin{array}{c}\text { Maksimal } \\
770\end{array}$ & SESUAI \\
\hline C1815 & & 708 & $\begin{array}{l}\text { Maksimal } \\
1000 \\
\text { Maksimal }\end{array}$ & SESUAI \\
\hline S9012 & FEP 123 & 689 & 1200 & SESUAI \\
\hline BC546B & & 723 & $\begin{array}{c}\text { Maksimal } \\
770 \\
\text { Maksimal }\end{array}$ & SESUAI \\
\hline BC557 & & 694 & 800 & SESUAI \\
\hline $\mathbf{S 8 0 5 0}$ & & 713 & $\begin{array}{l}\text { Maksimal } \\
1200\end{array}$ & SESUAI \\
\hline 2N3904 & & 733 & $650-850$ & SESUAI \\
\hline 2N5401 & & 689 & $\begin{array}{c}\text { Maksimal } \\
1000\end{array}$ & SESUAI \\
\hline A1015 & 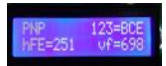 & 698 & $\begin{array}{c}\text { Maksimal } \\
1100\end{array}$ & SESUAI \\
\hline
\end{tabular}

Tabel 10 diatas menyajikan perbandingan antara data hasil perhitungan nilai vf (tegangan jepit antara kaki B dan E) BJT menggunakan alat uji BJT berbasis mikrokontroler yang telah dibuat dengan data rentang $\mathrm{V}_{\mathrm{BE}}$ BJT yang diperbolehkan dalam datasheet BJT yang bersangkutan. Dapat dilihat bahwa dari sample 10 BJT diatas, semua hasil pengujiannya sudah sesuai dengan datasheet, sehingga dapat disimpulkan bahwa alat uji BJT yang dibuat telah mampu melakukan perhitungan nilai vf BJT uji secara benar.

\section{Kesimpulan}

Berdasarkan pengujian dan analisis yang telah dilakukan, maka dapat disimpulkan bahwa Alat Uji Bipolar Junction Transistor Berbasis Mikrokontroler ini berhasil dibuat dengan beberapa parameter-parameter yang sudah ditentukan. Fungsionalitas seluruh sistem sudah memenuhi spesifikasi rancangan alat uji, pola yang diperoleh pada perancangan perangkat lunak sudah dapat meng-cover semua tipe BJT yang diuji sehingga hasil pengujian sistem ini sudah sesuai dengan datashhet BJT yang diuji. Dalam melakukan identikasi jenis BJT, konfigurasi kaki-kaki BJT uji, nilai penguatan (hFE), serta nilai tegangan forward (Vf atau $\mathrm{V}_{\mathrm{BE}}$ ), Alat Uji Bipolar Junction Transistor Berbasis Mikrokontroler ini telah dapat berfungsi dengan baik sesuai program yang ditentukan. 


\section{Referensi}

[1]. Sandy, Kiki Hery, "Realisasi Digital Transistor Tester Berbasis Mikrokontroler", Laporan Tugas Akhir, Fakultas Ilmu Terapan, Universitas Telkom, Bandung, 2010.

[2]. Hendriawan, Hendriawan, and Heni Puspita. Perancangan Dan Pembuatan Alat Penguji Dan Pengukur Penguatan Arus Transistor. INDEPT 2018; 3(3).

[3]. S, Arief Hendra, Wahyudi, Eka, S, Chandra A.P, "APLIKASI PERHUTUNGAN PEMBIASAN DC PADA TRANSISTOR DWI KUTUB NPN DENGAN VISUAL BASIC 6.0", Akademi Teknik Telekomunikasi Sandhy Putra Purwokerto, 2010.
[4]. Azizahwati, "PENGEMBANGAN MEDIA RANGKAIAN DASAR APLIKASI TRANSISTOR BIPOLAR", Pendidikan Fisika Universitas Riau.

[5]. Boylestad, Robert dan Nashelsky, Louis, Electronic Devices and Circuit Theory, Prentice Hall.

[6]. Perkasa, Dedy Bagus, "Perancangan Perangkat Keras Alat Uji Bipolar Junction Transistor Berbasis Mikrokontroler", Laporan Tugas Akhir, Fakultas Teknik, Universitas Diponegoro, Semarang, 2018.

[7]. Kubbeler, Karl-Heinz, "TRANSISTORTESTER WITH AVR MICROCONTROLLER AND A LITTLE MORE", Version 1.13k, 2017.

[8]. Surjono, Dwi Herman, Elektronika Teori dan Penerapan. Jember, Indonesia : Penerbit Cerdas Ulet kreatif, 2007. 